\title{
Assessing the hydrologic restoration of an urbanized area via an integrated distributed hydrological model
}

\author{
D. H. Trinh ${ }^{1}$ and T. F. M. Chui ${ }^{2}$ \\ ${ }^{1}$ Department of Civil and Environmental Engineering, National University of Singapore, Singapore, Singapore \\ ${ }^{2}$ Department of Civil Engineering, The University of Hong Kong, Hong Kong, China
}

Correspondence to: T. F. M. Chui (maychui@hku.hk)

Received: 5 December 2012 - Published in Hydrol. Earth Syst. Sci. Discuss.: 4 April 2013

Revised: 24 August 2013 - Accepted: 1 November 2013 - Published: 4 December 2013

\begin{abstract}
Green structures (e.g. green roof and bio-retention systems) are adopted to mitigate the hydrological impacts of urbanization. However, our current understanding of urbanization impacts are often process-specific (e.g. peak flow or storm recession), and our characterizations of green structures are often on a local scale. This study uses an integrated distributed hydrological model, Mike SHE, to evaluate the urbanization impacts on both overall water balance and water regime, and also the effectiveness of green structures at a catchment level. Three simulations are carried out for a highly urbanized catchment in the tropics, representing preurbanized, urbanized and restored conditions. Urbanization transforms vegetated areas into impervious surfaces, resulting in 20 and $66 \%$ reductions in infiltration and base flow respectively, and 60 to $100 \%$ increase in peak outlet discharge. Green roofs delay the peak outlet discharge by $2 \mathrm{~h}$ and reduce the magnitude by $50 \%$. Bio-retention systems mitigate the peak discharge by $50 \%$ and also enhance infiltration by $30 \%$. The combination of green roofs and bioretention systems even reduces the peak discharge to the preurbanized level. The simulation results obtained are independent of field data, enabling a generic model for understanding hydrological changes during the different phases of urbanization. This will benefit catchment-level planning of green structures in other urban areas.
\end{abstract}

\section{Introduction}

Urbanization transforms vegetated areas into impervious surfaces. This causes water flow to be redistributed by manmade structures and drainage networks, resulting in significant impacts on hydrological conditions (Antrop, 2004; Haase, 2009). The first and foremost impact is the change in water balance (DeFries and Eshleman, 2004). The replacement of vegetation with impervious surface leads to higher surface runoff and river discharge (Bhaduri et al., 2000; Dietz and Clausen, 2008; Wang et al., 2005; Du et al., 2012; Ott and Uhlenbrook, 2004; Sanders, 1986) and also reduces water losses through canopy interception, vegetation evapotranspiration and soil evaporation (Dow and DeWalle, 2000; Endreny, 2005; Rose and Peters, 2001). Besides surface water, urbanization also affects groundwater recharge (Barron et al., 2013). Some suggest that groundwater recharge increases due to the reduction in evapotranspiration (Klöcking and Haberlandt, 2002; Rose and Peters, 2001) and/or the leakage from water systems and sewers if the groundwater table is lower than the pipe level (Göbel et al., 2004; Lerner, 1990). Others believe that the additional impervious surfaces decrease groundwater recharge due to the reduction of infiltration (Collin and Melloul, 2003; Rose and Peters, 2001; Schoonover et al., 2006). Besides changing water balance, urbanization also influences water regime (i.e. pattern of flow), such as increasing and decreasing the high and low flows respectively, and also increases the daily variation in stream flow locally (Konrad and Booth, 2005). The storm recession period is also significantly shorter in urban streams (Rose and Peters, 2001). As listed above, there are numerous studies examining the hydrological impacts of urbanization.

Published by Copernicus Publications on behalf of the European Geosciences Union. 
Nevertheless, they mostly focus on the changes in particular components or processes, and examine the impacts on either water balance or water regime. There is thus an incentive to develop an integrated understanding on the overall changes in both water balance and water regime.

For environmental benefits and water resources management, there has been rising interest to mitigate the hydrological impacts of urbanization and to restore pre-urbanized hydrological conditions. One approach is to implement smallscale hydrologic control throughout a catchment. Examples of such hydrologic controls, known as "green structures" or "low-impact development practices", include green roofs and bio-retention systems. Even though there are many variants of green structures, green roofs and bio-retention systems are representative of most kinds of green structures as they comprise the main hydrologic restoration mechanisms of surface runoff delay and infiltration enhancement. Green roofs collect and retain rainwater falling onto buildings for a certain period of time (from hours to days) (Oberndorfer et al., 2007), thereby reducing and delaying water discharge to the drainage system. Studies have found that green roofs retain $40-80 \%$ of precipitation (Hutchinson et al., 2003; Palla et al., 2012; VanWoert et al., 2005) and reduce $60-80 \%$ of peak discharge (Bliss et al., 2009; Mentens et al., 2006; Palla et al., 2012; Villarreal et al., 2004). They also tend to retain a higher fraction of precipitation in small storms than in large ones (Carter and Rasmussen, 2006). On the other hand, bioretention systems not only retain stormwater (Xiao and Pherson, 2011) but also enhance infiltration (Davis, 2008; James and Dymond, 2012). Evaluating the effectiveness of bioretention systems, Holman-Dodds et al. (2003) concluded that they do not reduce runoff significantly on a site with low infiltration capacity; while Chang et al. (2009) emphasized that they are more effective when sited close to the watershed outlet. More quantitatively, Davis (2008) showed that with a $2 \%$ bio-retention system over 0.24 ha area, peak flow reduced by 44 to $63 \%$. However, most of the above studies are in plot-scale or small catchments, only evaluating the local impacts of an individual green structure.

The objective of this study is to assess the catchmentscale impact of urbanization on both water balance and water regime using an integrated distributed hydrological model, Mike SHE (System Hydrologique European). The model included all the main hydrological components (e.g. canopy interception, evapotranspiration, overland flow, river routing and groundwater) and detailed the spatial variations within a catchment. With the use of the integrated distributed hydrological model, the feasibility of restoring the hydrological condition is examined through the implementation of green roofs and bio-retention systems on a catchment scale.

\section{Methodology}

\subsection{The integrated distributed hydrological model}

Urbanization and green structures affect the interactions of various hydrological processes such as canopy interception, plant evapotranspiration, water and soil evaporation, infiltration, overland flow, and groundwater flow. Thus, an integrated hydrological model that accounts for all the above processes is needed to assess the hydrological impacts of urbanization and green structures. Compared to distributed models, lumped models have two main limitations. Firstly, the domain response is only evaluated at the outlet and sub-domain response is not considered. Furthermore, each characteristic of a catchment, despite its spatial variation, is lumped into one single parameter which may not truly represent the actual spatial distribution within the catchment. This research is interested in sub-domain response and also requires the considerations of the heterogeneous land uses including green structures in an urbanized catchment. Therefore, despite the high demand in input data and long computation time, a fully distributed model is more suitable for this study.

In particular, Mike SHE, a comprehensive deterministic, distributed, and physically based modelling system, is selected for this research. Mike SHE couples river routing modelling (Mike 11), overland flow and groundwater modelling, giving a complex integrated hydrological analysis of surface and subsurface water systems. It simulates all major processes in the land phase of the hydrological cycle, including precipitation, interception, infiltration, evapotranspiration, subsurface flow in unsaturated and saturated zones, overland flow and flow in the channel and river. Figure 1 shows the main components of Mike SHE and their governing equations. The Saint Venant equation is solved numerically in two dimensions for overland flow and in one dimension for channel flow. The one-dimensional Richards equation (or simplified gravity equation) is solved for the pressure head (or moisture) variation in the unsaturated zone. The horizontal movement of water in unsaturated zone is considered negligible. Saturated groundwater flow is simulated using the three-dimensional Boussinesq equation.

\subsection{Green roofs and bio-retention systems - conceptual understanding and model implementation}

\subsubsection{Green roof}

A green roof is a conventional roof covered with soil and vegetation, and consists of four main components: vegetation layer, soil layer, geotextile filter and drainage material (Czemiel Berndtsson, 2010). It functions as a microcatchment and includes all the main hydrological processes such as rainfall, plant interception, evapotranspiration, infiltration and storage. Though a green roof is often installed to save energy and to mitigate the urban heat island effect, 


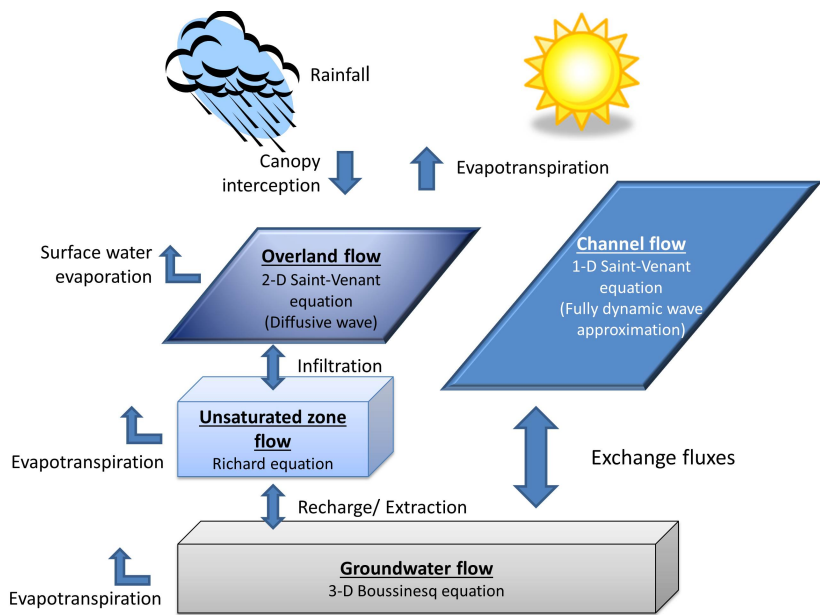

Fig. 1. Components of the integrated distributed hydrological model.

it has also been shown to benefit stormwater management (Bengtsson et al., 2005; Mentens et al., 2006; VanWoert et al., 2005). Rainfall needs to percolate and infiltrate through the vegetation and soil layers, thereby delaying runoff discharge as well as improving water runoff quality (Hathaway et al., 2008; Palla et al., 2010).

The key hydrological impact of a green roof during a storm event is the delay in runoff discharge. In Mike SHE, this delay in runoff discharge is simulated by delaying the rainfall in each individual green roof by $3 \mathrm{~h}$. The duration of delay is based on previously published studies; Moran et al. (2004) reported a delay time of $3 \mathrm{~h}$ and Rowe et al. (2003) found peak flow was delayed by 2 to $4.5 \mathrm{~h}$. Other important hydrological processes, e.g. infiltration, are simulated as part of the integrated model as explained in Sect. 2.1. However, the detailed flow processes within the different layers of a green roof, such as water storage and evapotranspiration, are not simulated given its high computational demand and small impact on predicting the overall discharge delay of a green roof. In terms of water storage, previous studies show that there is only a small amount of retention during large rainfall events (Carter and Rasmussen, 2006; VanWoert et al., 2005). The current model assumes no retention, which is conservative but acceptable as tropical rainfall is of high intensity and large rainfall events that potentially cause flooding problems are of interests. For evapotranspiration, we performed a measurement on a plot-scale green roof in Singapore and the results show that evapotranspiration accounts for $5 \%$ of total water balance. So, it is considered as insignificant and therefore also neglected in the green roof modelling. In addition, this study aims to develop a general idea on the effectiveness of catchment-scale green roof implementation without focusing on the detailed behaviour of each individual green roof. Therefore, simplifications made at individual green roof

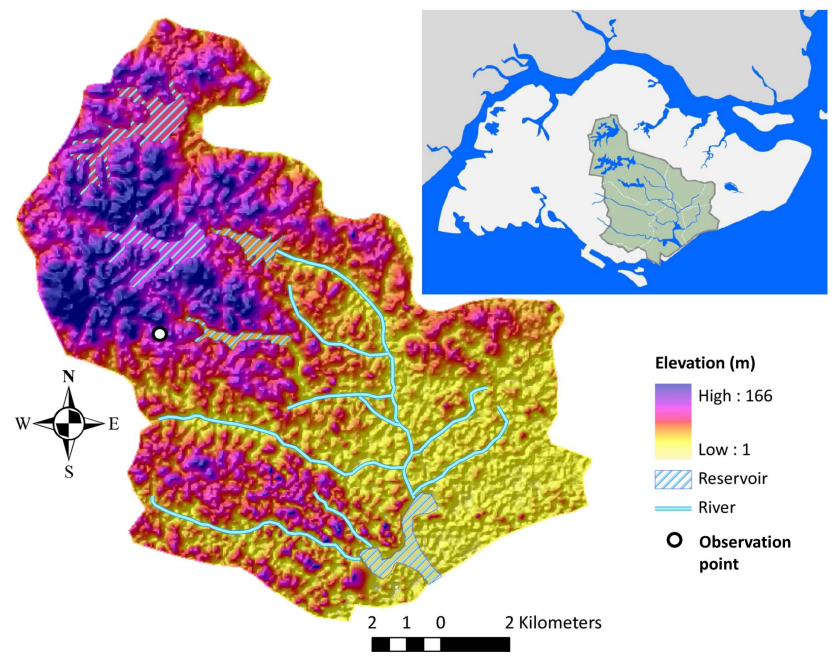

Fig. 2. Location of the Marina catchment within Singapore.

level would not affect the overall catchment-scale hydrological behaviours.

\subsubsection{Bio-retention system}

A bio-retention system is a shallow planted depression, and consists of ponding area, filter media, transition layer and drainage layer. It is one of the best stormwater management practices that provides both conveyance function and stormwater treatment. Stormwater runoff is filtrated through and treated by vegetation and soil within the bio-retention area. The filtrated water is either collected by a drainage system or allowed to infiltrate into the ground. To enhance infiltration into the system, it often employs filter media with a hydraulic conductivity of one to two orders of magnitude (i.e. 10 to 100 times) higher than that of the surrounding soil profile. In addition, the system allows ponding which provides further flow retention. In the integrated hydrological model, the bio-retention systems allow stormwater to infiltrate directly into the surrounding soil profile (i.e. no subsoil drainage). The bio-retention systems are modelled as homogenous soils with a high hydraulic conductivity of $10^{-5} \mathrm{~m} \mathrm{~s}^{-1}$, extending $1 \mathrm{~m}$ below the ground. The systems are also equipped with $20 \mathrm{~cm}$ of detention ponding. All the hydrological processes, e.g. evapotranspiration and infiltration, are also considered in the integrated model.

To implement green structures into the integrated hydrological model at catchment scale (area of $160 \mathrm{~km}^{2}$ ), resolving the catchment down to the scale of a single green structure system or even finer is one of the approaches. However, this requires high computational efforts and detailed input data. Therefore, one gird cell $(60 \mathrm{~m} \times 60 \mathrm{~m})$ is considered as an aggregated system of green roof or bio-retention. This method can reduce computational and input data requirements, with little penalty on prediction accuracy (Elliott et al., 2009). 


\subsection{Marina-like catchment - a case study in Singapore}

The biophysical and hydrological environment of Singapore has altered dramatically due to rapid urbanization and industrialization (Lu et al., 2005). The Marina catchment (Fig. 2), the most urbanized part of Singapore, has typical characteristics of a highly urbanized catchment in the tropical area. It has a catchment area of $160.8 \mathrm{~km}^{2}$, currently consists of different land uses and soil conditions, and includes the different components of hydrological and vegetation system (e.g. plant, river, reservoirs, mixture of permeable and impermeable surfaces). Adopting the main characteristics of the Marina catchment, an integrated distributed hydrological model of a Marina-like catchment is built to evaluate the impact of urbanization on water balances and regimes. In other words, this objective of this study is not to reproduce the exact situations of the Marina catchment, but rather to demonstrate the generic influences of urbanization on hydrological conditions. The model is further developed and applied to evaluate the effectiveness of catchment-scale green structures in mitigating the hydrological impacts of urbanization.

To address the issues raised in the objective, several simulations are performed. Firstly, to evaluate the effect of urbanization in Singapore, a pre-urbanized scenario in which all the hydrological conditions are at natural state is set up. It is then compared with an urbanized scenario in which all the hydrological factors are urbanized. Secondly, to evaluate the effectiveness of green structures in minimizing the impact of urbanization, another set of scenarios is set up to reflect the different strategies in installing the green structures in an urbanized environment. The results are then compared with those without the green structures to conclude their effectiveness. The simulation of each scenario is one year in duration, and is further elaborated below:

- The first scenario (pre-urbanized) represents the condition before urbanization in which the entire land surface is covered by plants and the rivers are in natural conditions.

- The second scenario (urbanized) represents the current situation in which the land surface coverage has changed drastically due to urbanization and is a combination of permeable and impermeable surfaces and buildings; rivers are also concrete-lined.

- The third scenario represents hypothetical situations in which green roofs and/or bio-retention systems are installed at strategic locations to mitigate the hydrological impacts of urbanization. This scenario is further divided into three different strategies:

- Strategy 1: restored by green roofs (Green roof). All the buildings in the catchment are covered with green roofs, which account for $14 \%$ of the catchment area.
- Strategy 2: restored by bio-retention systems (Bio-retention). Five (5) \% of the catchment area is converted from impervious surfaces in the urbanized scenario to bio-retention systems in this strategy. The bio-retention systems are located near the streams and are in areas where the groundwater table is at least $1.5 \mathrm{~m}$ below the ground.

- Strategy 3: restored by both green roofs and bioretentions (Hybrid). The hybrid is a combination of green roofs and bio-retention strategy.

To focus on the impacts resulting from the change from vegetated to impervious surface and the implementation of green structures, other factors such as climate, soil and topography are assumed not to change among the scenarios. Each scenario is run for one year under the same climate condition. The digital elevation model (DEM) SRTM (Shuttle Radar Topography Mission) (i.e. topography) in 2005 is obtained from the US Geological Survey with $30 \mathrm{~m}$ resolution (USGS, 2010) and are applied to all three scenarios. The surface mesh consists of 290 cells in east-west direction and 310 cells in north-south direction; each element is rectangular with a dimension of $60 \times 60 \mathrm{~m}$. The vertical discretization is chosen to match with the soil profile description and the required resolution of the simulation. In addition, the Richards equation is used to accurately simulate the infiltration process in the unsaturated zone. Therefore, 45 subsurface layers are used with a vertical discretization of $20 \mathrm{~cm}$ for the first $1 \mathrm{~m}$ depth, $50 \mathrm{~cm}$ for the following $5 \mathrm{~m}$ depth, and then $100 \mathrm{~cm}$ for the rest of the domain. Together with the surface mesh, the total domain has 4055500 elements. Each of the main hydrologic components has its own time step. River routing is the most dynamic process and is highly responsive to rainfall and topographical condition, followed by overland flow, and finally unsaturated and groundwater flow. In addition, to simulate the flow exchanges between the components, their time steps have to be even multiples of each other. For river routing, a time step of 1 minute is used. For overland flow, unsaturated and groundwater components, time steps of $0.25,0.5$ and $12 \mathrm{~h}$ are used respectively. This study examines the rapid response of peak outlet discharge (on timescales of minutes), as well as the long-term groundwater response (on timescales of days and months). Thus, the above time steps are chosen as compromises. When the time steps taken are finer than the data input, the model then linearly interpolates the data for the simulated time step.

\subsubsection{Surface and subsurface parameters}

To parameterize the surface and subsurface, the model domain is divided into zones based on the land cover, surface properties, soils, and geology. Land cover map (Fig. 3) is digitized from Singapore Master Plan in 2003 (URA, 2003), and is classified into four groups with vegetation of different 

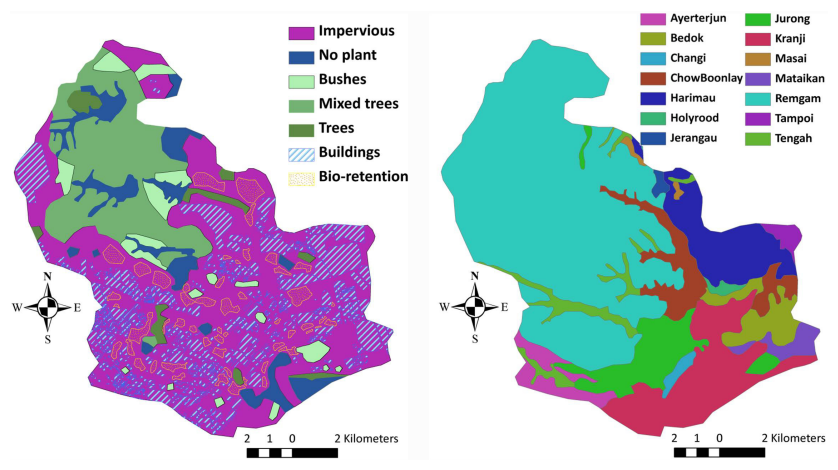

Fig. 3. Land cover (left) and soil distribution (right) of the Marinalike catchment 740 (Land use: 66\% impervious, including $14 \%$ building and $5 \%$ potential bio-retention area; $9 \% 741$ no plants; $25 \%$ plants, including $5 \%$ bushes, $18 \%$ mixed trees and $2 \%$ trees).

leaf area indices (LAI) and roof depths (RD) (Table 1). The tree heights in Singapore vary from 4 to $20 \mathrm{~m}$ (NPark, 2011). Based on the study of Štofko (2010) on the relationship between tree height and root depth, the corresponding average root depth should be approximately $5 \mathrm{~m}$. A recent survey in Singapore also shows that the root of vegetation can be more than $3 \mathrm{~m}$ (Ngo et al., 2013).

For soil properties, top soil (i.e. soil from surface up to $1 \mathrm{~m}$ depth) information is extracted from Singapore soil map (Fig. 3), digitized from the soil of the Republic of Singapore (Wells, 1977; Ives, 1977). Below $1 \mathrm{~m}$ depth, the soil is assumed to be loamy sand. Using the soil information from Table 2, together with the hydraulic parameters of standard soil texture from the United State Department of Agriculture, Van Genuchten parameters are estimated to define moisture retention and unsaturated hydraulic conductivity.

Regarding surface properties, detention storage is used to limit the amount of water that can flow over the ground surface; the depth of ponded water must exceed the detention depth before water is routed overland. For the Marinalike catchment, detention depth is generally set as $0.01 \mathrm{~mm}$ as the catchment is mostly covered by impervious surface. The detention depth for reservoirs is the maximum reservoir level, while the detention depth is set as $20 \mathrm{~cm}$ for areas with bio-retention systems based on Singapore's National Water Agency guideline for bio-retention system design (PUB, 2011). In Mike SHE, there is no explicit option to directly specify the partitioning of rainfall into direct runoff, infiltration and groundwater recharge as the model simulates the infiltration and subsurface water movement according to the different soil properties and rainfall conditions. However, one can specify the fraction of ponded water that drains to the drainage system. For this case study, $30 \%$ of the ponded water drains directly to the river network and the remaining $70 \%$ infiltrates. Surface roughness, defined by Manning number $(M)$ (inverse of the conventional Manning coefficient $n$ ), is 25 and 80 for surface covered with plant and open space, respectively. The values are equivalent to the Manning coefficient of 0.04 and 0.0125 , which are typical values for vegetated and concreted surface (Chow, 1959).

For geological properties, hydraulic parameters for the saturated zone are assumed to be loamy sand, a typical soil type in Singapore, for the entire catchment with a horizontal hydraulic conductivity of $1.22 \times 10^{-5}\left[\mathrm{~m} \mathrm{~s}^{-1}\right]$ and a vertical hydraulic conductivity equivalent to $10 \%$ of the horizontal hydraulic conductivity. Specific yield and specific storage is 0.2 [-] (Freeze and Cherry, 1979) and $9.82 \times 10^{-4} \mathrm{~m}^{-1}$ (Younger, 1993), respectively.

\subsubsection{Initial condition}

The initial condition of the integrated hydrological model is the combination of the initial conditions of different components such as ponding depth, soil moisture content and groundwater table. Ponding depth of reservoirs is assumed to be at the reservoir water levels, and is set at $0 \mathrm{~m}$ in the rest of the domain. To obtain an initial groundwater condition, a $10 \mathrm{yr}$ simulation is carried out. As the groundwater table in Singapore is only a few metres below the ground surface (Rezaur et al., 2003), the initial groundwater table for the $10 \mathrm{yr}$ simulation is set at $1.5 \mathrm{~m}$ below the ground. The climate condition of the year 2005 is repeated 10 times for this $10 \mathrm{yr}$ simulation. The groundwater table, reaching dynamic equilibrium after $10 \mathrm{yr}$, is then used as the initial condition of the remaining simulations. The initial condition sensitivity analysis of the results to the initial condition is also carried out. It is shown that within a reasonable range of initial conditions, the results converge to the same solutions. Initial soil moisture is set to achieve equilibrium pressure corresponding to the groundwater table from the $10 \mathrm{yr}$ simulation. In addition, for each $1 \mathrm{yr}$ scenario simulation, another $5 \mathrm{yr}$ of stabilization simulation is carried out to obtain dynamic equilibrium conditions of all the hydrological components, which are then used as the initial conditions for that particular scenario.

\subsubsection{Boundary conditions}

For the top boundary, precipitation is the only in-flux and evapotranspiration is the only out-flux. Rainfall and potential evapotranspiration are assumed to be uniformly distributed in the entire catchment. Hourly rainfall data from the year 2005 are obtained from the Kent Ridge campus of the National University of Singapore (NUS), located at the southwestern edge of the catchment. Evapotranspiration is calculated from Penman-Monteith method (Eq. 1) using hourly weather data (e.g. atmospheric pressure, air temperature, relative humidity, wind speed, and incoming radiation) from NUS for the year 2005 .

$\lambda E=\frac{\Delta\left(H_{\mathrm{net}}-G\right)+\rho_{\mathrm{air}} c_{p}\left(e_{z}^{0}-e_{z}\right) / r_{a}}{\Delta+\gamma\left(1+r_{c} / r_{a}\right)}$, 
Table 1. Vegetation characteristics.

\begin{tabular}{llcc}
\hline \multirow{2}{*}{ Vegetation Type } & Land Use & \multicolumn{2}{c}{ Vegetation Parameter } \\
\cline { 3 - 3 } Impervious & Residential, Business centre, Industry, & Leaf Area Index (-) & Root Depth (-) \\
& $\begin{array}{l}\text { Institution, Commercial, Military area, } \\
\text { Airfield, Port, Infrastructure }\end{array}$ & 0 \\
No plant & Reserve site, Cemetery & 0 & 0 \\
Bushes & Agriculture & 3 & 0 \\
Mixed trees & Open space, Recreation & 5 & 2000 \\
Trees & Park & 6 & 4000 \\
\hline
\end{tabular}

Table 2. Soil texture and properties.

\begin{tabular}{|c|c|c|c|c|c|c|c|c|c|c|c|}
\hline \multirow{2}{*}{ Soil Type } & \multirow{2}{*}{ Depth (cm) } & \multicolumn{3}{|c|}{ Soil Texture (\%) } & \multirow{2}{*}{$\mathrm{K}\left(\mathrm{m} \mathrm{s}^{-1}\right)$} & \multirow{2}{*}{ Soil Type } & \multirow{2}{*}{ Depth $(\mathrm{cm})$} & \multicolumn{3}{|c|}{ Soil Texture (\%) } & \multirow{2}{*}{$\mathrm{K}\left(\mathrm{ms}^{-1}\right)$} \\
\hline & & Sand & Silt & Clay & & & & Sand & Silt & Clay & \\
\hline \multirow[t]{4}{*}{ REMGAM } & $0-8$ & 78 & 2 & 20 & $1.76 \times 10^{-5}$ & \multirow[t]{4}{*}{ TAMPOI } & $0-6$ & 81.2 & 2.1 & 16.7 & $1.94 \times 10^{-5}$ \\
\hline & $8-34$ & 61 & 1 & 38 & $3.97 \times 10^{-6}$ & & $6-13$ & 72.5 & 1 & 26.5 & $3.70 \times 10^{-6}$ \\
\hline & $34-68$ & 57 & 3 & 40 & $4.04 \times 10^{-6}$ & & $13-44$ & 69.6 & 0 & 30.4 & $2.69 \times 10^{-6}$ \\
\hline & $68-160$ & 55 & 2 & 43 & $3.13 \times 10^{-6}$ & & $44-100$ & 61.7 & 0 & 38.3 & $2.69 \times 10^{-6}$ \\
\hline \multirow[t]{4}{*}{ JERANGAU } & $0-5$ & 35.7 & 6.1 & 58.2 & $1.42 \times 10^{-6}$ & \multirow{4}{*}{ CHOWBOONLAY } & $0-10$ & \multirow{4}{*}{\multicolumn{3}{|c|}{$\begin{array}{l}\text { Clay Loam } \\
\text { Silt Clay } \\
\text { Silt } \\
\text { Silt Clay }\end{array}$}} & $9.47 \times 10^{-7}$ \\
\hline & $15-30$ & 38 & 4 & 58 & $1.55 \times 10^{-6}$ & & $10-100$ & & & & $1.11 \times 10^{-6}$ \\
\hline & $30-82$ & 30 & 4 & 66 & $1.25 \times 10^{-6}$ & & $0-10$ & & & & $5.06 \times 10^{-6}$ \\
\hline & $82+$ & 28 & 3 & 69 & $1.26 \times 10^{-6}$ & & $10-100$ & & & & $1.11 \times 10^{-6}$ \\
\hline \multirow{4}{*}{ AYERTERJUN } & $0-7$ & 24 & 47 & 29 & $7.11 \times 10^{-6}$ & CHANGI & $0-100$ & \multirow{4}{*}{\multicolumn{3}{|c|}{$\begin{array}{c}\text { Sand } \\
\text { Loam Sand } \\
\text { Silt Clay } \\
\text { Silt Clay }\end{array}$}} & $7.44 \times 10^{-5}$ \\
\hline & $7-24$ & 23 & 44 & 33 & $1.53 \times 10^{-6}$ & HOLYROOD & $0-100$ & & & & $1.22 \times 10^{-5}$ \\
\hline & $24-60$ & 13 & 33 & 54 & $1.58 \times 10^{-6}$ & JURONG & $0-100$ & & & & $1.11 \times 10^{-6}$ \\
\hline & $60-135$ & 9 & 29 & 62 & $1.78 \times 10^{-6}$ & KRANJI & $0-100$ & & & & $1.11 \times 10^{-6}$ \\
\hline \multirow{4}{*}{ HARIMAU } & $0-14$ & 77.8 & 4 & 18.2 & $1.68 \times 10^{-5}$ & MATAIKAN & $0-100$ & \multirow{4}{*}{\multicolumn{3}{|c|}{$\begin{array}{c}\text { Sand Clay Loam } \\
\text { Clay } \\
\text { Loam Sand }\end{array}$}} & $1.53 \times 10^{-6}$ \\
\hline & $14-28$ & 73.5 & 4.1 & 22.4 & $5.74 \times 10^{-6}$ & MASAI & $0-100$ & & & & $1.71 \times 10^{-6}$ \\
\hline & $28-35$ & 69.8 & 3.1 & 27.1 & $3.41 \times 10^{-6}$ & TENGAH & $0-100$ & & & & $1.22 \times 10^{-5}$ \\
\hline & 53-94 & 57.8 & 1.2 & 41 & $2.16 \times 10^{-6}$ & & & & & & \\
\hline
\end{tabular}

where $\lambda$ is the latent heat of vaporization $\left(\mathrm{MJ} \mathrm{kg}^{-1}\right) ; E$ is the hourly potential evapotranspiration $\left(\mathrm{mm} \mathrm{h}^{-1}\right) ; \Delta$ is the slope of the saturation vapour pressure-temperature curve $\left(\mathrm{kPa}^{\circ} \mathrm{C}^{-1}\right) ; H_{\text {net }}$ is the net radiation $\left(\mathrm{MJ} \mathrm{m}^{-2} \mathrm{~h}^{-1}\right) ; G$ is the heat flux density to the ground $\left(\mathrm{MJ} \mathrm{m}^{-2} \mathrm{~h}^{-1}\right)$, which is assumed to be negligible in this study; $\rho_{\text {air }}$ is the air density $\left(\mathrm{kg} \mathrm{m}^{-3}\right) ; c_{p}$ is the specific heat at the constant pressure $\left(\mathrm{MJ} \mathrm{kg}^{-1}{ }^{\circ} \mathrm{C}^{-1}\right) ; e_{z}^{0}$ is the saturation vapour pressure of air at height $z(\mathrm{kPa}) ; e_{z}$ is the water vapour pressure of air at height $z(\mathrm{kPa}) ; \gamma\left(\mathrm{kPa}^{\circ} \mathrm{C}^{-1}\right)$ is the psychometric constant; $r_{c}$ is the plant resistance $\left(\mathrm{s} \mathrm{m}^{-1}\right)$; and $r_{a}$ is the diffusion resistance $\left(\mathrm{s} \mathrm{m}^{-1}\right)$.

For the boundary conditions on the sides, since the model domain is the entire Marina-like catchment, there are no fluxes across the inland boundary. The boundary bordering the sea is assumed to have a fixed head of $0 \mathrm{~m}$ corresponding to the mean sea level. This boundary is independent from tidal fluctuation due to the existence of the Marina Barrage.
Reservoirs in the catchment are set as internal boundary conditions with head-controlled flux. The exchange fluxes depend on the head difference between the groundwater table and the reservoir water depth with a leakage coefficient of $10^{-3} \mathrm{~s}^{-1}$. The bottom boundary of the domain is bed rock and thus has no flux. Due to the lack of detailed geology data, the bedrock is assumed to be at a constant depth of $30 \mathrm{~m}$ below the ground. This assumption will not affect the shallow groundwater movement in the shallow subsurface environment (i.e. in the top few metres), which is the focus of this study.

\subsubsection{River routing}

The main river network of the Marina-like catchment is delineated from the DEM and published documents from Singapore's National Water Agency (PUB, 2007). Most of the channel cross sections are assumed to be rectangular, except 


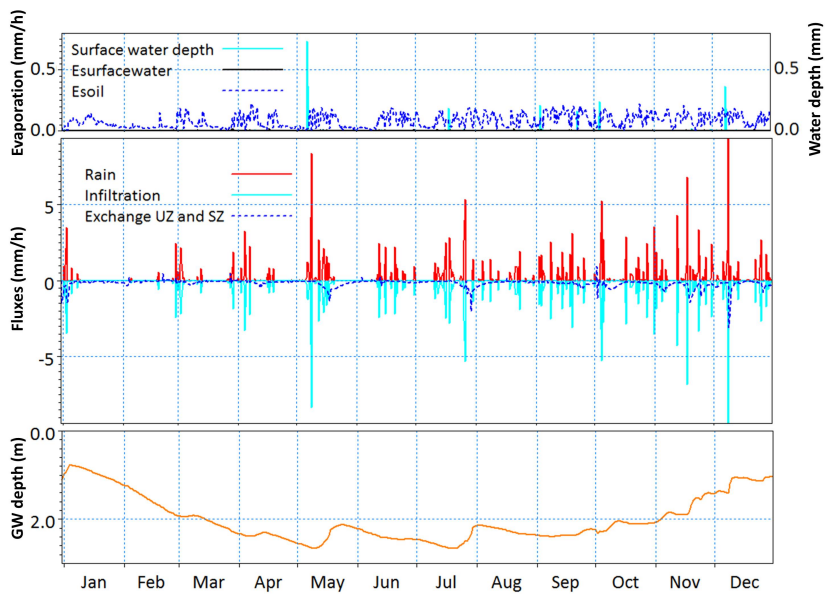

Fig. 4. Water balance at observation point (indicated in Fig. 2) in catchment equipped with bio-retention systems (Esoil: evaporation from soil; Esurfacewater: evaporation from surface water (underneath by the dotted blue line); exchange UZ and SZ: exchange between unsaturated and saturated zone; GW depth: groundwater table depth).

the main river flow from north to south of the catchment (i.e. Kallang River) that has the addition of the trickle channel (also known as a dry weather flow channel that is constructed along the centre and lowest part of a channel to carry low flows). The channel width is estimated based on remote sensing data and the channel elevation is estimated from DEM data. Inflow boundary at the upstream is set at a constant discharge value of $0 \mathrm{~m}^{3} \mathrm{~s}^{-1}$. Downstream, water level is at a constant elevation of $11 \mathrm{~m}$ which is approximately the level of the Marina reservoir (the most southern and downstream reservoir). $M$ is 25 and 80 for earthen and concrete river banks, respectively. The fluxes exchanged between groundwater and surface water in the channel are estimated using a leakage coefficient of $10^{-5}$. For the stabilization of the model, initial water depth and discharge are at $0.1 \mathrm{~m}$ and $0 \mathrm{~m}^{3} \mathrm{~s}^{-1}$, respectively.

\section{Results}

\subsection{Impacts on overall water balance}

To determine the impacts on water balance, the different hydrological components and their temporal variations at the observation point (indicated in Fig. 2) are examined (Fig. 4). The selected location is near the main river and in the midstream of the catchment, which is highly urbanized. The results, extracted from the bio-retention scenario, indicate that the hydrologic processes are temporally dynamic due to the changes in rainfall. For example, in the beginning of January, during the event with a rainfall intensity of $3.5 \mathrm{~mm} \mathrm{~h}^{-1}$, the infiltration rate is slightly less than $3.5 \mathrm{~mm} \mathrm{~h}^{-1}$. The top soil is saturated, producing a downward flux from the unsaturated

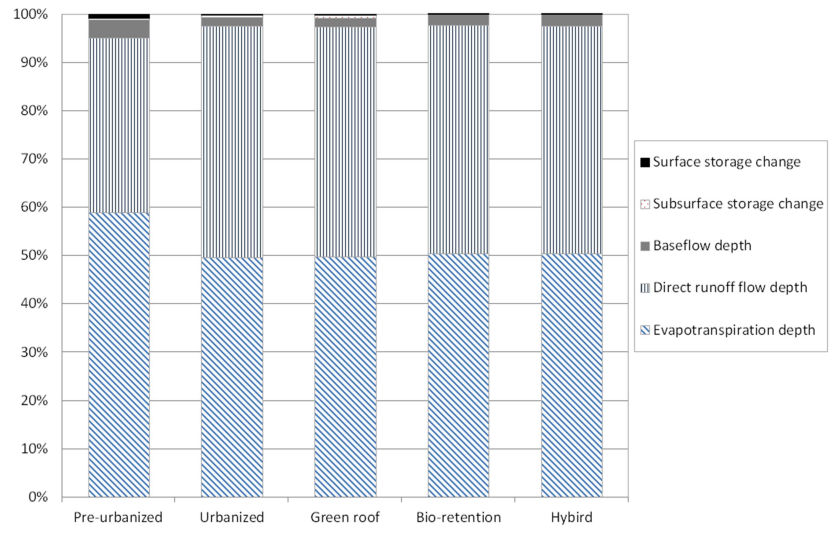

Fig. 5. Water balance aggregated over one year for different scenarios.

to the saturated zone at the rate of $2 \mathrm{~mm} \mathrm{~h}^{-1}$. Due to the series of rainfall events, groundwater table rises by $0.2 \mathrm{~m}$. During the relatively dry period of mid-January to mid-February, there are no downward fluxes from the unsaturated to the saturated zone. As the top soil dries out gradually, the moisture in the unsaturated zone is not enough to support the evaporation process; water is therefore taken from the saturated zone, leading to a gradual drawdown in the groundwater table.

The only influx to the catchment is rainfall, and it either turns into outfluxes (e.g. base flow, direct runoff flow and evapotranspiration) or increases the storage within the system (e.g. canopy storage, surface water storage and subsurface water storage). Figure 5 presents the distribution of rainfall into the different components aggregated over one year for the different scenarios. Canopy storage is not shown in the figure as it is negligible compared to other components. The surface and subsurface storage changes in all the scenarios are also insignificant (less than $0.5 \%$ of total water balance). This is because these storage changes in the model are changes of storage from one year to the next. As the simulations are repeated for $5 \mathrm{yr}$ with the same climatic input, the model should reach a dynamic steady state (dynamic equilibrium condition) and the storage changes in the reporting year, which is the last year of the simulation run, should be minimal.

For all scenarios, the greatest contributing factor is evapotranspiration. Compared to the other scenarios, there is a higher fraction (10\% more) of evapotranspiration in the preurbanized scenario since the entire land surface is covered by trees. There is a drastic increase (by $20 \%$ ) in the direct runoff in the urbanized scenario due to the change of $66 \%$ land use from pervious to impervious surfaces. Corresponding to a large amount of direct runoff in the urbanized scenario, base flow depth is reduced by almost $66 \%$ in the urbanized scenario when compared to the pre-urbanized one. The base flow depth is also not increased by green roofs, and it only increases marginally with the implementation of bio-retention 


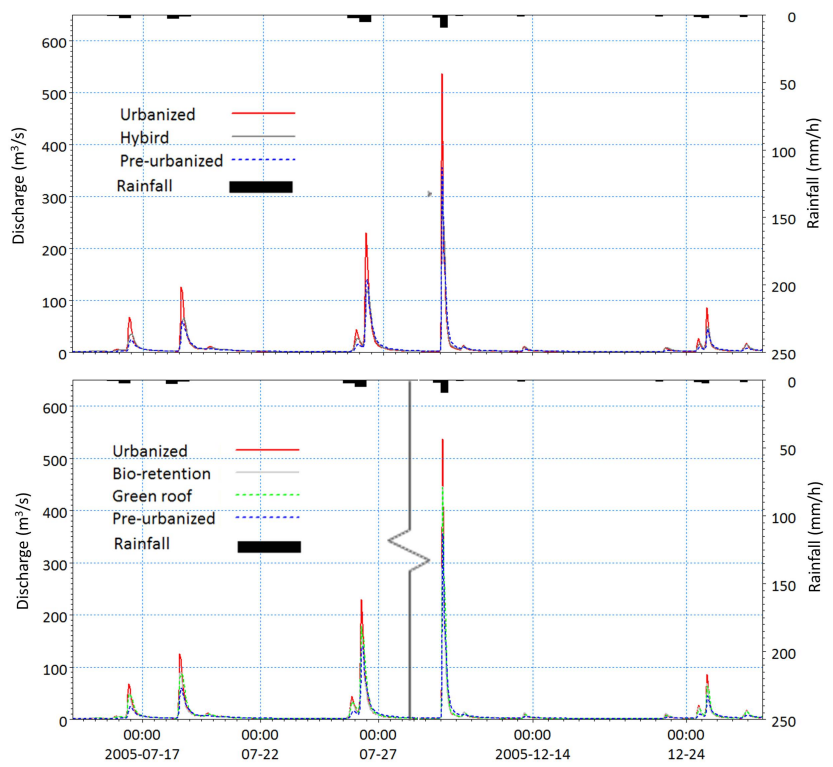

Fig. 6. Peak discharges at catchment outlet under different scenarios.

systems in either the bio-retention or hybrid scenarios due to the enhancing infiltration function of bio-retention systems.

\subsection{Impacts on eminent water resources issues}

\subsubsection{Flash floods}

To study the impact of urbanization and the strategies in averting flash floods, river discharge is first analysed. Urbanization increases the peak outlet discharge significantly (Fig. 6). During rainfall events of small intensity (e.g. 13 and 28 December) and average intensity (e.g. 17, 19 July and 26 December), peak outlet discharge increases by more than $100 \%$. For rainfall events with high intensity (26 July and 8 December), the percentage increase is smaller (about $60 \%$ ). However, the magnitudes of peak discharge for smalland average-intensity rainfall are small. Thus, the high percentage increase in fact does not have significant impact on the catchment. On the other hand, although the percentage increase of high-intensity rainfall is smaller, it has significant impact as the magnitude of peak discharge is relatively high. The highest peak outlet discharge in the urbanized scenario is $550 \mathrm{~m}^{3} \mathrm{~s}^{-1}$, leading to potential flash floods in the low-lying areas.

Besides assessing the impact of urbanization, the effectiveness of each strategy in reducing the flood risk is also examined. Overall, all the restoration strategies reduce the peak discharge. In average-intensity rainfall events, the green roof scenario or the bio-retention scenario reduces the peak discharge by $25 \%$. The hybrid scenario can fully reduce the peak flow to the pre-urbanized level. For example, the rainfall event on 19 July produces a peak outlet discharge

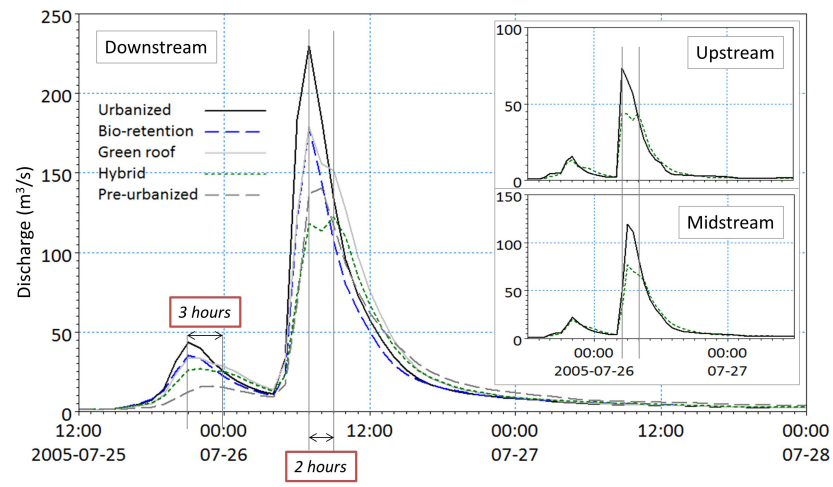

Fig. 7. Delay of peak discharges for different sections (i.e. downstream, midstream and upstream) of the main river of catchment.

of $60 \mathrm{~m}^{3} \mathrm{~s}^{-1}$ in the pre-urbanized scenario; this amount increases to $125 \mathrm{~m}^{3} \mathrm{~s}^{-1}$ in the urbanized scenario. The installation of either green roofs or bio-retention systems brings the peak discharge from $125 \mathrm{~m}^{3} \mathrm{~s}^{-1}$ down to $90 \mathrm{~m}^{3} \mathrm{~s}^{-1}$. For the case in which both green roofs and bio-retention systems are installed, the peak discharge is the same as in the preurbanized scenario. In the case of high-intensity rainfall, focusing on the highest rainfall event in the simulation year, on 8 December, a rainfall depth of $136 \mathrm{~mm}$ in $5 \mathrm{~h}$ results in an outlet peak discharge of $550 \mathrm{~m}^{3} \mathrm{~s}^{-1}$ under urbanized conditions. Installation of either green roofs or bio-retention systems decreases the peak discharge to $450 \mathrm{~m}^{3} \mathrm{~s}^{-1}$, and the installation of both structures decreases the peak discharge to $330 \mathrm{~m}^{3} \mathrm{~s}^{-1}$, which is even lower than the peak discharge of $350 \mathrm{~m}^{3} \mathrm{~s}^{-1}$ in the pre-urbanized scenario. This is due to the combined effect of green structures: the delay of rainfall by green roofs and the enhancement of infiltration by bio-retention systems. To conclude, the large-scale restoration strategy restores the pre-urbanized condition effectively in terms of outlet discharge, reducing the potential flooding problems.

Other than examining the magnitude of peak discharges, Fig. 7 compares the peak time to evaluate peak delays in each restoration scenario. Taking the rainfall event on 26 July as an example, the downstream peak outlet discharge in the urbanized and the bio-retention scenarios occurs at the same time. However, there are two peaks in the green roof and hybrid scenarios, with the first peak occurring slightly later in the urbanized scenario and the second peak delayed for another $2 \mathrm{~h}$. This is due to the existence of green roofs, which delay discharge for about $3 \mathrm{~h}$ in both scenarios. The hydrograph on 25 July also gives similar results except that the time of delay varies depending on the rainfall characteristics. Although the double peaks only occur in simulations and may be indistinct during field observations, the results do illustrate the peak attenuation due to green roofs. 


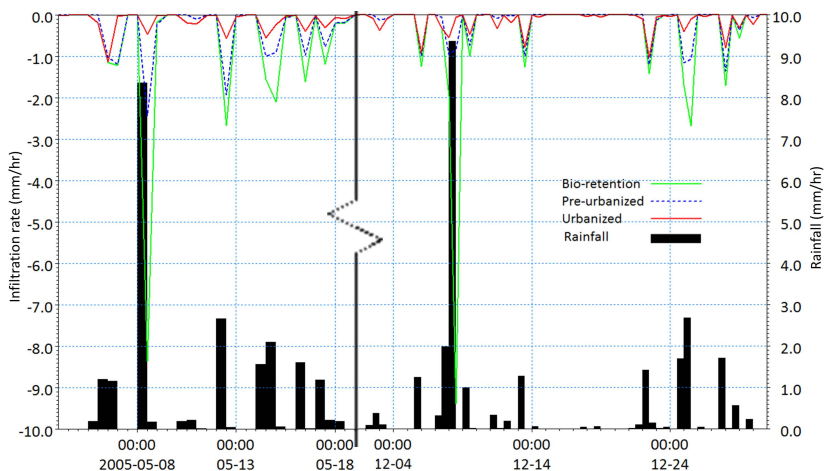

Fig. 8. Infiltration rate at observation point (indicated in Fig. 2) in catchment.

Besides comparing the peak time downstream, one can also examine the change of delay along the channel from upstream to midstream and subsequently downstream. Focusing on only the hybrid scenario, the relative heights of the two peaks vary between upstream, midstream and downstream due to the merging of secondary rivers which are at different locations from green structures. Furthermore, there is a slight increase in the delay of the peak from upstream to downstream due to the propagation of waves along the river. Overall, examining the peak timing and its propagation through the river network demonstrates the importance of a catchment-level planning of green structures (in terms of locations as well as the percentage of surface coverage) in mitigating floods.

\subsubsection{Groundwater replenishment}

The main source of groundwater replenishment in this catchment is from surface water infiltrating into the ground. Urbanization not only increases the peak river discharge but also decreases the infiltration rate, preventing surface water from going into the ground and recharging subsurface storage. As mentioned in the water balance section, green roofs do not significantly change the water budget or enhance infiltration rate. This section therefore focuses on comparing the infiltration rates in the urbanized, pre-urbanized and bio-retention scenarios to evaluate the effectiveness of bioretention systems in enhancing infiltration. For plot scale, the infiltration rates at one particular location where land use has changed from pervious to impervious and then to bioretention system is compared (Fig. 8). The infiltration rate is highest in the bio-retention scenario and is equal to the rainfall rate. As a result, there can be local groundwater mounds in which the groundwater table is about 1 to $2 \mathrm{~m}$ higher than the surrounding environment. However, this should not affect the main underground infrastructure in Singapore (e.g. the underground transport system which is approximately $30 \mathrm{~m}$ below the ground). Other infrastructures (e.g. pipes) within the shallow subsurface environment are also often below the

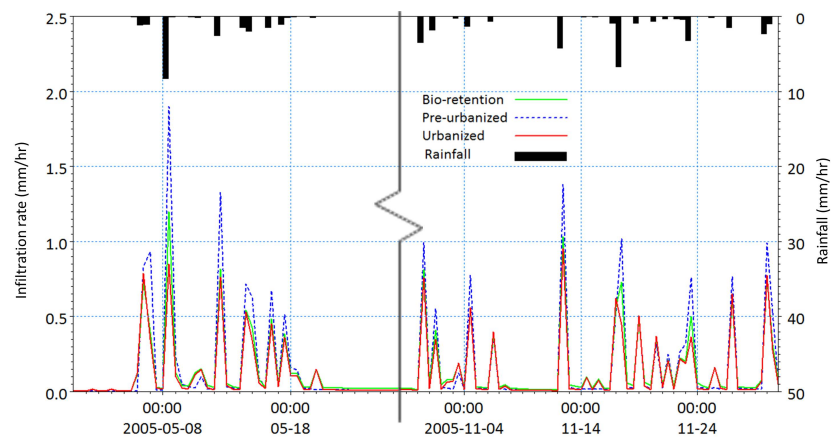

Fig. 9. Average infiltration rate of entire catchment under different scenarios.

groundwater table and are designed for submerged condition. The impervious concrete surfaces in an urbanized catchment such as buildings, roads and pavements prevent infiltration. The infiltration rate of the entire catchment in 2005 is reduced by $20 \%$ in the urbanized scenario as compared to the pre-urbanized scenario, while the bio-retention scenario restores $10 \%$. The actual infiltration rate under different scenarios (Fig. 9) varies temporally depending on the rainfall intensity as well as the time interval between two consecutive rainfall events. There is significantly less infiltration in the urbanized scenario during high intensity rainfall events such as those on 9 May, 12 November and 17 November. The decrease can be as high as 40 to $50 \%$, compared to only 10 to $15 \%$ in average rainfall events such as those from 14 to 18 May or from 31 October to 5 November. Bio-retention systems restore 20 to $30 \%$ and 5 to $10 \%$ of the pre-urbanized infiltration during high and average rainfall events respectively. For all the small rainfall events (e.g. 11 and 20 May and 15 November), the infiltration rate of the bio-retention scenario is higher than that in the pre-urbanized scenario. Most of the small rainfall events occur closely in time. In the pre-urbanized condition, the soil is fully saturated after several events. Water can no longer infiltrate and contributes to surface runoff. However, more water can infiltrate in the bioretention systems because the detention ponding provides additional time for water to infiltrate into the ground.

\subsection{Model sensitivity analysis}

\subsubsection{Rainfall resolution and simulation time step}

To examine the influence of rainfall resolution and simulation time step on peak outlet discharge, two additional simulations are carried out: (1) original rainfall data interval $(1 \mathrm{~h})$ but coarser simulation time steps ( $5 \mathrm{~min}$ for river routing, $0.5 \mathrm{~h}$ for overland flow, $1 \mathrm{~h}$ for unsaturated flow, and $12 \mathrm{~h}$ on groundwater flow); (2) rainfall data of smaller interval (5 min) with the original simulation steps.

The "representative" peak outlet discharges (i.e. highest peak, medium peak and small peak) of the above two 
simulations are extracted and compared with those from the original simulation. The results show that the increase in simulation step sizes does not affect the time and the magnitude of the peak discharges. The more detailed rainfall input increases the peak discharges at most by $20 \mathrm{~m}^{3} \mathrm{~s}^{-1}$, and changes the time of occurrence by at most $1 \mathrm{~h}$.

\subsubsection{Soil hydraulic conductivity of bio-retention system}

Two simulations using bio-retention systems with soil hydraulic conductivity of $5 \times 10^{-5} \mathrm{~m} \mathrm{~s}^{-1}\left(180 \mathrm{~mm} \mathrm{~h}^{-1}\right)$ and $10^{-4} \mathrm{~m} \mathrm{~s}^{-1}\left(360 \mathrm{~mm} \mathrm{~h}^{-1}\right)$, which are higher than the original value of $10^{-5} \mathrm{~m} \mathrm{~s}^{-1}\left(36 \mathrm{~mm} \mathrm{~h}^{-1}\right)$, are carried out. In terms of outlet discharge, the results show that the difference among the scenarios is insignificant. In terms of infiltration rate and groundwater recharge, results from a bio-retention system at the centre of the catchment are extracted. Particularly, the groundwater table, infiltration rate and groundwater recharge across the system $12 \mathrm{~h}$ after the largest rainfall event in the simulated year are further explained as an example. This event has a rainfall depth of $130 \mathrm{~mm}$ and an intensity of $26 \mathrm{~mm} \mathrm{~h}^{-1}$. The infiltration rates of the different scenarios are the same, as the rainfall intensity is lower than the soil hydraulic conductivities of the bio-retention systems. There is more recharge to the saturated zone at that particular moment leading to a higher groundwater table in the scenario with higher soil hydraulic conductivity. However, the total recharges of all scenarios reach the same values eventually. The temporal difference in groundwater recharge is because rain water requires different duration to travel through the unsaturated zone to reach the saturated zone depending on the soil hydraulic conductivity of the bio-retention system.

\subsubsection{Soil hydraulic conductivity of native soil}

To assess the influence of soil hydraulic conductivity on rainfall partitioning to recharge and runoff, different scenarios with a soil hydraulic conductivity that is one order of magnitude lower are simulated.

For the aggregated water balance over one year, the rainfall partitioning still follows the same patterns as the original simulation. For example, when compared with the preurbanized scenario, there is still close to a $10 \%$ increase of direct runoff and $10 \%$ decrease in evapotranspiration in the urbanized and hybrid scenarios. There is also more base flow in the hybrid scenario when compared to the urbanized one due to the green structures.

In terms of peak outlet discharge, the low hydraulic conductivity leads to an increase of peak discharge by $50 \mathrm{~m}^{3} \mathrm{~s}^{-1}$ in the pre-urbanized scenario. Similarly, the decrease in hydraulic conductivity also results in a higher peak discharge in the hybrid scenario. However, the amount of increase, $100 \mathrm{~m}^{3} \mathrm{~s}^{-1}$, is higher than the pre-urbanized one. This is because the low hydraulic conductivity of the native soil not only reduces rainfall infiltration but also limits the exfiltra- tion of the bio-retention system. The change in hydraulic conductivity however does not significantly affect the peaks in the urbanized scenario due to the low percentage of pervious area. Although the absolute values of peak discharges change with the hydraulic conductivity, the relative differences among the scenarios are still the same. In other words, there is still a drastic increase of peak discharge in the urbanized scenario and a partial recovery in the hybrid one.

\section{Discussion}

The following key points underpin the analysis of the hydrological characteristics of the different scenarios. Firstly, evapotranspiration accounts for a relatively high percentage of water budgets in all scenarios. It therefore should not be neglected; otherwise this might lead to overestimations of the other components. Secondly, groundwater plays an important role and should be taken into consideration, especially when the hydrological changes in shallow groundwater systems are examined. The exchange between groundwater and surface water depends on the difference in groundwater level and surface water level, as well as the soil moisture content in the unsaturated zone. In shallow groundwater systems, it is even possible to have groundwater exfiltration during heavy rainfall in low-lying areas. Thirdly, different designs of green structures (e.g. green roofs versus bio-retention systems) provide different hydrological functions and their relative locations within the catchment also yield different outcomes at the catchment outlet. Therefore, it is possible to integrate different green structures at optimized locations to achieve specific targets such as reducing flash floods, enhancing groundwater replenishment, or restoring the pre-urbanized hydrograph at the catchment outlet. Last but not least, the sensitivity analysis on rainfall data resolution, simulation time step, and soil hydraulic conductivities of the bio-retention system and native soils leads to certain changes in the modelling results. However, the changes are not significant enough to affect the main conclusions of this study.

\section{Summary and conclusions}

This study assesses the overall hydrological impacts of urbanization and the effectiveness of catchment-scale green structures in restoring pre-urbanized hydrological conditions. A physically based integrated distributed hydrological model, Mike SHE, is used to simulate a highly urbanized catchment in the tropics under three main scenarios (i.e. pre-urbanized, urbanized and restored) that differ in their land uses. The most important findings are summarized as follows: 
1. In terms of the hydrological impacts of transforming $66 \%$ of the vegetated area into impervious surface and changing the vegetation type in the remaining area during urbanization, the following is observed:

- Infiltration on average reduces by $20 \%$, which is proportional to the increase of impervious surface. There is thus less subsurface water recharge and less subsurface water storage. The actual reduction in each rainfall event varies with rainfall intensity and time interval from the previous rainfall event.

- Base flow decreases by $66 \%$ and surface runoff increases by $20 \%$, leading to a higher potential of flash floods. The peak outlet discharge increases by $100 \%$ during low- and averageintensity rainfall and by $60 \%$ in high-intensity rainfall. Although the percentage increase is lower, the increase of discharge during highintensity rainfall is more impactful due to the relatively high pre-urbanized value.

2. To mitigate the hydrological impacts of urbanization, three catchment-scale green structure strategies are explored:

- The first strategy is to install green roofs in all the buildings, accounting for $14 \%$ of the catchment area. The green roofs retain rainfall for $3 \mathrm{~h}$ but exert minimal changes in water balance or infiltration. They do however reduce the peak outlet discharge by 30 to $50 \%$ and delay the peak by $2 \mathrm{~h}$, and thus can mitigate flash floods in urban areas.

- The second strategy is to set up bio-retention systems in $5 \%$ of the catchment area. Bio-retention systems are modelled as $1 \mathrm{~m}$-deep soils with relatively high hydraulic conductivity of $10^{-5} \mathrm{~m} \mathrm{~s}^{-1}$. On average, infiltration for the catchment increases by $10 \%$. The actual increase in each event depends on the rainfall condition and can be as high as $30 \%$ during rainfall with high intensity. Base flow increases and surface runoff decreases, and this second strategy can therefore also mitigate flash floods.

- The third strategy is to implement a combination of the previous two strategies (i.e. installing $14 \%$ green roofs and $5 \%$ bio-retention). It provides the functions of both types of structures (e.g. improving water balance, enhancing infiltration rate, delaying peak outlet discharge), and manages to reduce the peak outlet discharge down to, and in some cases even lower than, the pre-urbanized value.
3. Assessing the hydrologic restoration of an urbanized area via the case study, further conclusions can be made:

- Evapotranspiration is one of the important processes and should not be neglected as it accounts for a relatively high percentage of the water budget.

- Groundwater plays an important role, especially in shallow groundwater systems, as it has direct dynamic effects on the infiltration rate and the water exchange between groundwater and surface water.

- It is feasible to re-shape the outlet hydrograph via large-scale hydrological controls throughout a catchment, but it is important to perform catchment-scale planning for the desired integrated spatial and temporal effects.

The simulation results obtained are independent of field data, enabling a generic model for understanding hydrological changes during the different phases of urbanization. The results and conclusions drawn are thus beneficial and applicable to catchment-level water resource planning and management in many urban areas worldwide, especially those in the tropical region.

\section{Supplementary material related to this article is available online at http://www.hydrol-earth-syst-sci.net/ 17/4789/2013/hess-17-4789-2013-supplement.pdf.}

Acknowledgements. The research was supported by Academic Research Fund (AcRF) Tier 1 from the Singapore Ministry of Education (MOE) (FRC grant R-302-000-007-112).

Edited by: A. Shamseldin

\section{References}

Antrop, M.: Landscape change and the urbanization process in Europe, Landsc. Urban Plann., 67, 9-26, doi:10.1016/s01692046(03)00026-4, 2004.

Barron, O. V., Barr, A. D., and Donn, M. J.: Effect of urbanisation on the water balance of a catchment with shallow groundwater J. Hydrol., 485, 162-0176, doi:10.1016/j.jhydrol.2012.04.027, 2013.

Bengtsson, L., Grahn, L., and Olsson, J.: Hydrological function of a thin extensive green roof in southern Sweden, Nord. Hydrol., 36, 259-268, 2005.

Bhaduri, B., Harbor, J., Engel, B., and Grove, M.: Assessing watershed-scale, long-term hydrologic impacts of land-use change using a GIS-NPS model, Environ. Manage., 26, 643-658, 2000 . 
Bliss, D. J., Neufeld, R. D., and Ries, R. J.: Stormwater runoff mitigation using a green roof, Environ. Eng. Sci., 26, 407-417, doi:10.1089/ees.2007.0186, 2009.

Carter, T. L. and Rasmussen, T. C.: Hydrological behavior of vegetated roofs, JAWRA J. Am. Water Resour. Assoc., 42, 12611274, doi:10.1111/j.1752-1688.2006.tb05299.x, 2006.

Chang, C. L., Lo, S. L., and Huang, S. M.: Optimal strategies for best management practice placement in a synthetic watershed, Environ. Monit. Assess., 153, 359-364, doi:10.1007/s10661008-0362-y, 2009.

Chow, V. T.: Open-Channel Hydraulics, McGraw-Hill, 1959.

Collin, M. L. and Melloul, A. J.: Assessing groundwater vulnerability to pollution to promote sustainable urban and rural development, J. Cleaner Product., 11, 727-736, doi:10.1016/s09596526(02)00131-2, 2003.

Czemiel Berndtsson, J.: Green roof performance towards management of runoff water quantity and quality: A review., Ecol. Eng., 36, 351-360, doi:10.1016/j.ecoleng.2009.12.014, 2010.

Davis, A.: Field performance of bioretention: Hydrology impacts, J. Hydrol. Eng., 13, 90-95, doi:10.1061/(ASCE)10840699(2008)13:2(90), 2008.

DeFries, R. and Eshleman, K. N.: Land-use change and hydrologic processes: a major focus for the future, Hydrol. Process., 18, 2183-2186, doi:10.1002/hyp.5584, 2004.

Dietz, M. E. and Clausen, J. C.: Stormwater runoff and export changes with development in a traditional and low impact subdivision, J. Environ. Manage., 87, 560-566, doi:10.1016/j.jenvman.2007.03.026, 2008.

Dow, C. L. and DeWalle, D. R.: Trends in evaporation and Bowen ratio on urbanizing watersheds in eastern United States, Water Resour. Res., 36, 1835-1843, 2000.

Du, J., Qian, L., Rui, H., Zuo, T., Zheng, D., Xu, Y., and Xu, C. Y.: Assessing the effects of urbanization on annual runoff and flood events using an integrated hydrological modeling system for Qinhuai River basin, China, J. Hydrol., 464-465, 127-139, doi:10.1016/j.jhydrol.2012.06.057, 2012.

Elliott, A., Trowsdale, S., and Wadhwa, S.: Effect of aggregation of on-site stormwater control devices in an urban catchment model, J. Hydrol. Eng., 14, 975-983, doi:10.1061/(ASCE)HE.19435584.0000064, 2009.

Endreny, T. A.: Evaporation, in: Water Encyclopedia, John Wiley \& Sons, Inc, 2005.

Freeze, R. A. and Cherry, J. A.: Groundwater, Englewood Cliffs, New Jersey, Prentice Hall, 1979.

Göbel, P., Stubbe, H., Weinert, M., Zimmermann, J., Fach, S., Dierkes, C., Kories, H., Messer, J., Mertsch, V., Geiger, W. F., and Coldewey, W. G.: Near-natural stormwater management and its effects on the water budget and groundwater surface in urban areas taking account of the hydrogeological conditions, J. Hydrol., 299, 267-283, doi:10.1016/j.jhydrol.2004.08.013, 2004.

Haase, D.: Effects of urbanisation on the water balance - A longterm trajectory, Environ. Impact Assess. Rev., 29, 211-219, doi:10.1016/j.eiar.2009.01.002, 2009.

Hathaway, A., Hunt, W. F., and Jennings, G.: A field study of green roof hydrologic and water quality performance, Trans. ASABE, 51, 37-43, 2008.

Holman-Dodds, J. K., Bradley, A. A., and Potter, K. W.: Evaluation of hydrologic benefits of infiltration based urban stormwater management, J. Am. Water Resour. Assoc. (JAWRA), 39, 205215, doi:10.1111/j.1752-1688.2003.tb01572.x, 2003.

Hutchinson, D., Abrams, P., Retzlaff, R., and Liptan, T.: Stormwater monitoring two ecorrofs in Portland, Oregon, USA, in: Greening Rooftops for Sustainable Communites, Chicago, 2003.

Ives, D. W.: Soil of the Republic of Singapore, in: New Zealand Soil Bureau Scientific Report, Soil Bureau, Lower Hutt, New Zealand, 1977.

James, M. and Dymond, R.: Bioretention hydrologic performance in an urban stormwater network, J. Hydrol. Eng., 17, 431-436, doi:10.1061/(ASCE)HE.1943-5584.0000448, 2012.

Klöcking, B. and Haberlandt, U.: Impact of land use changes on water dynamics - a case study in temperate meso and macroscale river basins, Phys. Chem. Earth, Parts A/B/C, 27, 619-629, doi:10.1016/s1474-7065(02)00046-3, 2002.

Konrad, C. P. and Booth, D. B.: Hydrologic changes in urban streams and their ecological significance, in: American Fisheries Society Symposium, Alaska, 157-177, 2005.

Lerner, D. N.: Groundwater recharge in urban areas, in: Hydrological Processes and Water Management in Urban Areas, IAHS, 1990.

Lu, X. X., Wong, P. P., and Chou, L. M.: Singapore's Biophysical Environment, Singapore, The McGraw Hill, 2005.

Mentens, J., Raes, D., and Hermy, M.: Green roofs as a tool for solving the rainwater runoff problem in the urbanized 21st century?, Landsc. Urban Plann., 77, 217-226, doi:10.1016/j.landurbplan.2005.02.010, 2006.

Moran, A., Hunt, B., and Jennings, G.: A north Carolina field study to evaluate greenroof runoff quantity, runoff quality, and plant growth, in: 2nd Greening Rooftops for Sustainable Communities Conference, Portland, 446-460, 2004.

Ngo, K. M., Turner, B. L., Muller-Landau, H. C., Davies, S. J., Larjavaara, M., Nik Hassan, N. F. b., and Lum, S.: Carbon stocks in primary and secondary tropical forests in Singapore, Forest Ecol. Manage., 296, 81-89, doi:10.1016/j.foreco.2013.02.004, 2013.

NPark: Greenery provision for roadside, N. P. Board (N. P. Board), Singapore, 2011.

Oberndorfer, E., Lundholm, J., Bass, B., Coffman, R. R., Doshi, H., Dunnett, N., Gaffin, S., KÖHler, M., Liu, K. K. Y., and Rowe, B.: Green roofs as urban ecosystems: Ecological structures, functions, and services, BioScience, 57, 823-833, 2007.

Ott, B. and Uhlenbrook, S.: Quantifying the impact of land-use changes at the event and seasonal time scale using a processoriented catchment model, Hydrol. Earth Syst. Sci., 8, 62-78, doi:10.5194/hess-8-62-2004, 2004.

Palla, A., Gnecco, I., and Lanza, L. G.: Hydrologic restoration in the urban environment using green roofs, Water, 2, 140-154, 2010.

Palla, A., Gnecco, I., and Lanza, L. G.: Compared performance of a conceptual and a mechanistic hydrologic models of a green roof, Hydrol. Process., 26, 73-84, doi:10.1002/hyp.8112, 2012.

PUB: ABC waters master plan for the central catchment, in: $\mathrm{ABC}$ Waters Master Plan, Public Utility Board (Water), Singapore, 2007.

PUB: Design guidelines Public Utilities Board, Singapore, 2011.

Rezaur, R. B., Rahardjo, H., Leong, E. C., and Lee,, T. T.: Hydrologic behavior of residual soil slopes in Singapore, J. Hydrol. Eng., 8, 133-144, 2003.

Rose, S. and Peters, N. E.: Effects of urbanization on streamflow in the Atlanta area (Georgia, USA): a comparative 
hydrological approach, Hydrol. Process., 15, 1441-1457, doi:10.1002/hyp.218, 2001.

Rowe, D., Rugh, C., VanWoert, N., Monterusso, M., and Russell, D.: Green roof slope, substrate depth, and vegetation influence runoff, in: 1st North American Green Roof Conference: Greening Rooftops for Sustainalbe Communities, Chicago, 354-362, 2003.

Sanders, R. A.: Urban vegetation impacts on the hydrology of Dayton, Ohio, Urban Ecol., 9, 361-376, doi:10.1016/03044009(86)90009-4, 1986.

Schoonover, J. E., Lockaby, B. G., and Helms, B. S.: Impacts of land cover on stream hydrology in the West Georgia Piedmont, USA, J. Environ. Qual., 35, 2123-2131, 2006.

Stofko, P.: Relationships between the parameters of aboveground parts and the parameters of root plates in Norway spruce with respect to soil drainage, J. FOR. SCI, 56, 353-360, 2010.

URA: Singapore Master Plan in 2003 Urban Redevelopment Authority Singapore, 2003

USGS: USGS Global Visualization Viewer USGS Global Visualization Viewer Virginia, 2010.
VanWoert, N. D., Rowe, D. B., Andresen, J. A., Rugh, C. L., Fernandez, R. T., and Xiao, L.: Green roof stormwater retention: Effects of roof surface, slope and media depth, J. Environ. Qual., 34, 1036-1044, doi:10.2134/jeq2004.0364, 2005.

Villarreal, E. L., Semadeni-Davies, A., and Bengtsson, L. Inner city stormwater control using a combination of best management practices, Ecol. Eng., 22, 279-298, doi:10.1016/j.ecoleng.2004.06.007, 2004.

Wang, Y., Choi, W., and Deal, B. M.: Long-term impacts of landuse change on non-point source pollutant loads for the St. Louis Metropolitan Area, USA, Environ. Manage., 35, 194-205, 2005.

Wells, N.: The role of soils in the utilisation of sewage sludge in Singapore, in: New Zealand Soil Bureau Scientific Report, Soil Bureau, Lower Hutt, New Zealand, 1977.

Xiao, Q. and McPherson, E. G.: Performance of engineered soil and trees in a parking lot bioswale, Urban Water J., 8, 241-253, doi:10.1080/1573062x.2011.596213, 2011.

Younger, P. L.: Simple generalized methods for estimating aquifer storage parameters, Q. J. Eng. Geol. Hydrogeol. 26, 127-135, 1993. 